\title{
高分子論文集「ポリマーと環境」特集号 投稿論文の募集
}

[対象]

1. 環境保全に役立つ高分子機能材料

（1）水の浄化, 炭酸ガス固定, 重金属分離, 土壤改良等

2. プラスチックの再生利用

(1) プラスチック分離・分別および微粉砕

(2) 複合材料としての再生利用

(3) 再生利用に有効な充填剂, 相溶化剂

(4) モノマーへのケミカルリサイクル，エネルギー資源化

(5) リサイクルを考えたモノマーやポリマーの設計

3. 分解性プラスチックス

（1）分解性（生分解性, 光分解性）ポリマーの合成, 分子設計

(2) 分解の機構

（3）天然高分子の生分解性ポリマーへの応用

(4) 分解性ポリマーの利用

(5) 分解性試験評価方法

4. 医用高分子の廃棄による污染とその防止

原稿編切 1993 年 4 月 30 日（当日消印有効）

原稿の方き＼cjkstart普通号の投稿論文の場合と同じ（「投稿規定」をご参照下さい）

論文の取扱い方＼cjkstart通常の審查規定に基づいて採否を決定いたします. 内容によっては，編集委員 会で審議の上, 普通号の一般論文にまわすこともありますので, 予めご了承下 さい.

申 込 先 巴104 東京都中央区築地 2-4-2 高分子学会

高分子論文集・出版委員会 803-3543-3772 Fax. 03-3545-8560

\section{〔訂正のお知らせ〕}

水酸化アルミニウム充てん BMC (Bulk Molding Compounds) の難燃性効果 小林亜男, 尾形正次, 石川鉄雄, 松 延詊次, 高分子論文集 (Kobunshi Ronbunshu), Vol. 50, No. 2. pp. 99-106 (Feb., 1993)

\begin{tabular}{|c|c|c|c|c|c|c|}
\hline 個 & \multicolumn{3}{|c|}{ 誤 } & \multicolumn{3}{|c|}{ 正 } \\
\hline p. 99 右段 2.1 試料の節 上から 5 行目 & \multicolumn{3}{|c|}{ 日本触媒(株)製 } & \multicolumn{3}{|c|}{ 日本油脂(株)製 } \\
\hline \multirow{2}{*}{$\begin{array}{l}\text { p. } 100 \text { Table } 1 \text { Sample No. } 5,6,7 \text { の閥 } \\
\text { 上から } 9 \text { 行目 }\end{array}$} & \multicolumn{3}{|c|}{ Sample No. } & \multicolumn{3}{|c|}{ Sample No. } \\
\hline & 5 & 6 & 7 & 5 & 6 & 7 \\
\hline \multirow{3}{*}{ Reinforcing agent Glass fiber $の$ 行 } & $\ldots$ & $\ldots$ & $\ldots$ & $\ldots$ & $\ldots$ & $\ldots$ \\
\hline & 0.9 & 0.9 & 0.9 & 9.0 & 9.0 & 9.0 \\
\hline & $\ldots$ & $\ldots$ & $\ldots$ & $\ldots$ & $\ldots$ & $\ldots$ \\
\hline
\end{tabular}

